DOI: $10.29303 /$ jrpb.v8i1.170

ISSN 2301-8119, e-ISSN 2443-1354

Tersedia online di http://jrpb.unram.ac.id/

\title{
SIFAT FISIK DAN MEKANIS LEMBARAN KERING SELULOSA BAKTERI BERBAHAN DASAR LIMBAH HASIL PERTANIAN
}

\author{
The Physical and Mechanical Characteristics of Dried Bacterial Cellulosa \\ Made from Waste of Agricultural Product Processing
}

\author{
I Wayan Sweca Yasa*), Eko Basuki, Satrijo Saloko, Dody Handito \\ Fakultas Teknologi Pangan dan Agroindustri, Universitas Mataram \\ J1. Majapahit No. 62, Mataram 83125, Indonesia

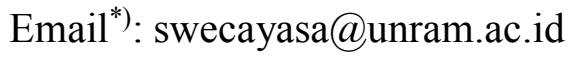 \\ Diterima: Desember 2019 \\ Disetujui: Februari 2020
}

\begin{abstract}
The purity of microbial cellulose, particularly bacterial cellulose, depends on the carbon source, purification methods and the acetilation process. This research aim was to identify the appropriate of carbon source from different agricultural waste and the method of purification to produce a dried bacterial cellulose with physical and mechanical characteristics that met the standard of bioplastics for food packaging. The experiments were conducted in laboratory and arranged with completely randomized designs of two factors and three replications. The factors were type of agricultural waste dan methods of purification. The agricultural waste consisted of coconut water, tofu whey, and the waste of pineapples peeling. The purification methods were hidrolyses bacterial cellulose with caustic soda of $0.1 \%$ at $100^{\circ} \mathrm{C}$ for 30 minutes and at $30^{\circ} \mathrm{C}$ for 24 hours. Data was analyzed with analyses variance at 5 percent level of signficancy and post hoc test with Honestly Significant Difference (HSD) at the same level of significancy. The result showed that interaction between the type of agricultural waste and methods of purification did not affect the physical and mechanical characteristics of the dried bacterial cellulose product. The coconut water from copra production produced the bacterial cellulose with the best physical and mechanical characteristics. The dried bacterial cellulose of coconut water had brownish in colour, smooth, and slighy shrinkage on the surface, the thickness and rendemen was $0.11 \mathrm{~cm}$ and $5.35 \%$ respectively and the tensile strength, elongation as well as the modulus Young was $74.40 \mathrm{MPa}, 7.36 \%, 2664.16$, respectively. The methods of purification with caustic soda of $0.1 \%$ at $100^{\circ} \mathrm{C}$ for 30 minutes had better effect on physical and mechanical characteristic of dried bacterial cellulosa than the caustic soda of $0.1 \%$ at $30^{\circ} \mathrm{C}$ for 24 hours
\end{abstract}

Keywords: waste, purification, cellulose

\begin{abstract}
ABSTRAK
Bioselulosa (BS) terutama selulosa bakteri, tingkat kemurniannya tergantung dari bahan baku pembuatan BS, metode pemurnian dan proses asetilasi. Penelitian ini bertujuan untuk mengidentifikasi jenis bahan limbah pertanian dan metode pemurnian yang tepat untuk
\end{abstract}


mendapatkan karakteristik BS kering dengan sifat fisik dan mekanis sesuai dengan standar bahan plastik mudah terurai (biodegradable). Penelitian dilaksanakan melalui percobaan di laboratorium. Percobaan ditata menggunakan rancangan acak lengkap faktorial dengan dua faktor. Faktor pertama adalah bahan baku selulosa bakteri, yang terdiri atas 3 aras, yaitu 1) Sumber C dari air kelapa, 2) Whey tahu, dan 3) Kulit dan bongkol nenas. Faktor kedua adalah metode pemurnian BS dengan 2 aras perlakuan, yaitu 1) Hidrolisis BS dengan $\mathrm{NaOH} 0,1 \%$ bertemperatur $100^{\circ} \mathrm{C}$ selama 30 menit, dan 2) Hidrolisis BS dengan $\mathrm{NaOH} 0,1 \%$ bertemperatur $30^{\circ} \mathrm{C}$ selama 24 jam. Data dianalisis menggunakan analisis keragaman pada taraf nyata 5 persen dan uji lanjut menggunakan uji Beda Nyata Jujur pada taraf nyata yang sama. Hasil percobaan menunjukkan bahwa sifat fisik dan mekanis BS kering tidak dipengaruhi oleh interaksi antara jenis bahan baku BS dan metode pemurnian. Bahan baku BS kering yang dibuat dari air kelapa limbah pembuatan kopra memiliki sifat fisik dan mekanis yang terbaik dengan warna coklat krem, permukaan halus, sedikit kerutan, ketebalan dan rendemen berturut turut sebesar $0,11 \mathrm{~cm}$ dan 5,35\%, serta kuat tarik 74,40 MPa, elongasi 7,36\% dan modulus Young 2664,16. Pemurnian BS denganNaOH $0,1 \%$ bertemperatur $100^{\circ} \mathrm{C}$ selama 30 menit menghasilkan BS kering dengan sifat fisik dan mekanis yang lebih baik dibandingkan dengan $\mathrm{NaOH} 0,1 \%$ bertemperatur $30^{\circ} \mathrm{C} 24$ jam.

Kata kunci: limbah, pemurnian, selulosa

\section{PENDAHULUAN}

\section{Latar belakang}

Kemasan berperan penting untuk melindungi dan mengawetkan makanan. Kemasan berbahan dasar biologis (biobased packaging) lebih disukai saat ini karena kekhawatiran akan dampak terhadap lingkungan jika menggunakan kemasan yang sulit terurai (non-biodegradable). Selulosa bakteri (bio-selulosa) merupakan bahan yang cocok untuk pembuatan kemasan mudah terurai (biodegradable) (Tang, dkk., 2010) karena terdiri dari jaringan halus, dapat terurai secara hayati (Sonia dan Dasan, 2013), dan kinerja ketahanan air yang tinggi (Arrieta, dkk., 2014). Bahkan bio-selulosa (BS) merupakan bahan pilihan yang sangat baik untuk kemasan makanan, akan tetapi BS tidak memiliki sifat antibakteri dan antioksidan dan untuk mencegah kontaminasi makanan. Karena itu, BS perlu penambahan bahan lain kedalamnya untuk mendapatkan sifat-sifat kemasan seperti disebut di atas (Gao, dkk., 2014). BS yang ditambahkan dengan bahan lain dinamakan BS komposit. BS komposit anti mikroba misalnya, dapat ditambahkan dengan nisin sehingga BS komposit ini dapat digunakan untuk kemasan daging
(Nguyen, dkk., 2008); sosis (Zhu, dkk., 2010), atau untuk memperpanjang masa simpan telur (Suppakul, dkk., 2010), mempercepat ketersediaan vitamin $\mathrm{C}$ (Perez, dkk., 2013). Namun demikian, pembuatan kemasan pangan dengan BS komposit membutuhkan tingkat kemurnian BS yang tinggi agar produk kemasan yang dihasilkan dapat berfungsi sesuai dengan perannya dan efektif dalam mempertahankan mutu produk.

Salah satu yang mempengaruhi tingkat kemurnian BS adalah metode pemurnian. Proses pemurnian BS dapat dilakukan dengan perendaman menggunakan larutan alkali seperti $\mathrm{NaOH}$ atau $\mathrm{KOH}$, larutan asam organik seperti asam asetat atau dengan pencucian dengan air panas (Chawla, dkk., 2009) atau kombinasi antara perendaman dengan larutan alkali, asam asetat dan perebusan (Bielecki, dkk., 2005). Hasil penelitian Meftahi, dkk., (2015) dan Maryam, dkk., (2017) menunjukkan bahwa teknik pemurnian BS dengan menggunakan kombinasi pemanasan dengan larutan $\mathrm{NaOH} 0,1 \mathrm{~N}$ dan dinetralkan dengan asam asetat serta direndam dalam aquades menghasilkan BS dengan warna lebih transparan, ukuran pori lebih besar, daya 
serap air berkurang dan kemampuan membasahi meningkatkan. Akan tetapi menurut Santos, dkk., (2014) menyatakan bahwa pemurnian dengan alkali membuat ukuran pori BS menjadi lebih kecil, indeks kristalinnya meningkat dan sifat mekanisnya menjadi lebih baik, jika dibandingkan dengan BS tanpa pemurnian.

Selain pemurnian, metode pengeringan juga sangat berpengaruh terhadap sifat fisik dan mekanis BS (Zeng, dkk., 2014). Pengeringan BS dengan pengering beku merupakan merupakan metode pengeringan BS yang paling tepat untuk mendapatkan karakterisitik BS sebagai bahan kemasan (Basak, 2013; Norhayati, dkk., 2014; Meftahi, dkk., 2015). Akan tetapi pengeringan beku membutuhkan biaya yang mahal dan teknik prosesnya agak kompleks, jika dibandingkan dengan metode pengeringan konvensional seperti pengeringan dengan udara panas dan panas statis.

\section{Tujuan dan Manfaat Penelitian}

Penelitian ini bertujuan untuk menentukan metode pemurnian dan pengeringan yang tepat dari BS asal limbah pertanian dalam upaya mendapatkan bahan baku BS yang bermutu untuk pembuatan kemasan pangan mudah terurai (biodegradable). Penelitian ini diharapkan dapat memberikan informasi tentang metode pemurnian dan pengeringan BS sebagai bahan baku kemasan serta teknologi praktis dalam pembuatan BS bermtu.

\section{METODE PENELITIAN}

\section{Alat dan Bahan}

Alat-alat yang digunakan dalam penelitian ini antara lain: Universal Testing Machines merk ANO model RTG-1310, Jepang dengan beban maksimum $10 \mathrm{kN}$, mikrometer, timbangan analitik model AA200, penyaring, kompor, pH-meter, termometer, pengaduk, alumunium foil, gelas ukur, gelas kimia, pipet ukur, spatula, bak fermentasi, pengempa hidrolik, kain saring tahu, rak penjemur, termohigrometer digital merk HTC-2, Cina. Bahan-bahan yang digunakan dalam penelitian ini antara lain air kelapa, limbah cair tahu, kulit buah nenas, Acetobacter xylinum, asam asetat $\left(\mathrm{CH}_{3} \mathrm{COOH}\right)$, gula $\left(\mathrm{C}_{12} \mathrm{H}_{22} \mathrm{O}_{11}\right)$, amonium sulfat $\left(\left(\mathrm{NH}_{4}\right)_{2} \mathrm{SO}_{4}\right)$, asetat anhidrida $\left(\left(\mathrm{CH}_{3} \mathrm{CO}\right)_{2} \mathrm{O}\right)$, soda kaustik $(\mathrm{NaOH})$, kertas saring, dan aquades.

\section{Metode}

Percobaan ditata menggunakan rancangan acak lengkap faktorial $3 \times 2$ dengan 3 ulangan. Faktor yang diteliti adalah jenis bahan sumber karbon (air kelapa dari limbah kopra, whey tahu dari limbah pembuatan tahu, dan kulit nenas dari hasil pengupasan nenas) dan metode pemurnian (hidrolisis menggunakan $\mathrm{NaOH}$ $0,1 \%$ bertemperatur $100^{\circ} \mathrm{C}$ selama 30 menit dan hidrolisis menggunakan $\mathrm{NaOH} 0,1 \%$ bertemperatur $30^{\circ} \mathrm{C}$ selama 24 jam). Parameter yang diamati meliputi: 1) sifat fisik bioselulosa (nata) kering yang meliputi warna, bentuk permukaan, penyusutan, ketebalan dan rendemen, 2) Sifat mekanis nata kering yang meliputi kuat tarik, kemuluran (elongasi) dan modulus Young. Data hasil percobaan dianalisis menggunakan analisis keragaman pada taraf nyata 5\% dan uji lanjut mengggunakan Uji Beda Nyata Jujur (Honestly Significant Differences) pada taraf nyata 5\% (Senecdor dan Cohran, 1994).

\section{Prosedur percobaan}

Pembuatan selulosa bakteri (nata)

Air kelapa, whey tahu, atau sari buah (juice) kulit nenas yang telah disaring sebanyak $1 \mathrm{~L}$ dipanaskan dan ditambahkan 60 gram gula pasir, 20gram urea, $15 \mathrm{ml}$ asam asetat. Larutan yang dipanaskan tersebut dituangkan ke dalam bak fermentasi (loyang plastik) dan ditutup rapat dengan alumunium foil dan dilubangi, kemudian simpan di ruang yang gelap. Setelah dingin, dituangi stater Acetobacter xylinum sebanyak $200 \mathrm{ml}$. Fermentasi dilakukan selama 18 hari. 
Pemurnian Selulosa Bakteri

Selulosa bakteri (pelikel) yang dihasilkan dari proses fermentasi dipisahkan dari larutannya dengan cara ditiriskan dan direndam dengan aquades selama 24 jam. Air perendam diganti setiap 6 jam. Pelikel yang telah terpisah dicuci dengan air bebas ion, kemudian direndam dalam larutan $\mathrm{NaOH} \quad 0,1 \%$ pada suhu $100^{\circ} \mathrm{C}$ selama 30 menit dan larutan $\mathrm{NaOH} \quad 0,1 \%$ pada suhu $30^{\circ} \mathrm{C}$ selama 24 jam (sesuai perlakuan pemurnian). Setelah direndam dinetralkan dengan penambahan asam asetat $1 \%$ pada suhu kamar selama 24 jam. Pelikel hasil penetralan dipress dengan hand press kemudian dikeringkan dengan cara dijemur di bawah sinar matahari selama 3 hari. Selulosa bakteri kering kemudian dikemas dengan kantung plastik polipropelin dan dimasukkan ke dalam wadah kedap udara untuk siap dilakukan pengamatan sifat fisik dan mekanisnya.

\section{HASIL DAN PEMBAHASAN}

Hasil pengamatan secara kualitatif dilakukan pada sifat fisik lembaran selulosa bakteri (nata) kering diperlihatkan pada Tabel 1. Lembaran selulosa bakteri kering dibuat dari air kelapa hasil limbah pembuatan kopra, whey tahu dari limbah pembuatan tahu, dan kulit buah nenas dari limbah pengolahan minimal (minimally processing) buah nenas. Lembaran selulosa bakteri dimurnikan sebelum dikeringkan dengan cara dihidrolisis menggunakan larutan $\mathrm{NaOH} 0,1 \%$ pada suhu $100^{\circ} \mathrm{C}$ dan $30^{\circ} \mathrm{C}$. Setelah dimurnikan, masing-masing lembaran selulosa bakteri itu dipress dengan hand press untuk mengurangi kandungan airnya, kemudian dikeringkan dengan cara dijemur selama 3 hari. Sifat fisik lembaran kering selulosa bakteri yang diperoleh diamati secara kualitatif. Variabel yang diamati adalah warna, kenampakan dan kerutan (shrinkage). Hasil pengamatan sifat fisik seperti ketebalan dan rendemen lembaran kering selulosa bakteri dan sifat mekanisnya ditentukan secara kuantitatif seperti diperlihatkan pada Tabel 2.

Jenis bahan pembuatan selulosa bakteri berpengaruh terhadap ketebalan dan rendemen kering selulosa bakteri (nata) yang terbentuk, namun metode pemurnian tidak berpengaruh terhadap ketebalan dan rendemen nata (Tabel 2). Metode pemurnian hanya berpengaruh terhadap sifat mekanis nata kering seperti kuat tarik, elongasi dan modulus Young. Interaksi antara jenis bahan nata dan metode pemurnian tidak berpengaruh terhadap sifat fisik dan mekanis nata kering yang dihasilkan sebagaimana diperlihatkan pada Tabel 3.

Tabel 1. Hasil Pengamatan Sifat Fisik Lembaran Kering Selulosa Bakteri dari Berbagai Jenis Limbah dan Metode Pemurnian yang Berbeda.

\begin{tabular}{lllcc}
\hline \multicolumn{1}{c}{ Jenis } & \multicolumn{1}{c}{ Metode } & \multicolumn{2}{c}{ Variabel sifat fisik lembaran selulosa bakteri } \\
\cline { 3 - 5 } \multicolumn{1}{c}{ Limbah } & \multicolumn{1}{c}{ Hidrolisis } & Warna & Kenampakan & Kerutan \\
\hline 1. Air kelapa & Direndam dalam & Coklat krem & Halus & Sedkit \\
2. Whey tahu & larutan NaOH & Coklat muda & Kasar & Banyak \\
3. Kulit nenas & $0,1 \%$ bersuhu & Putih kecoklatan & Halus & Sedikit \\
& $100^{\circ} \mathrm{C}$ selama 30 & & & \\
& menit & & & \\
1. Air kelapa & Direndam dalam & Coklat gelap & Agak kasar & Agak banyak \\
2. Whey tahu & larutan NaOH & Coklat tua & Kasar & Banyak \\
3. Kulit nenas & $0,1 \%$ bersuhu & Coklat muda & Agak kasar & Agak banyak \\
& $30^{\circ} \mathrm{C}$ selama 24 & & & \\
& jam & & & \\
\hline
\end{tabular}


Tabel 2. Pengaruh Jenis Bahan Nata Terhadap Sifat Mekanis, Rendemen dan Ketebalan Lembaranan Nata Kering

\begin{tabular}{lccccc}
\hline $\begin{array}{l}\text { Jenis bahan } \\
\text { baku nata }\end{array}$ & $\begin{array}{c}\text { Kuat tarik } \\
\text { (Tensile } \\
\text { strength) } \\
\text { (MPa) }\end{array}$ & $\begin{array}{c}\text { Kemuluran } \\
\text { (Elongation) } \\
(\%)\end{array}$ & $\begin{array}{c}\text { Modulus } \\
\text { Young }\end{array}$ & $\begin{array}{c}\text { Ketebalan } \\
(\mathrm{cm})\end{array}$ & $\begin{array}{c}\text { Rendemen } \\
(\%)\end{array}$ \\
\hline Air kelapa (J1) & $74,40 \pm 1,65 \mathrm{c}$ & $7,36 \pm 0,003 \mathrm{c}$ & $2664,16 \pm 75,03 \mathrm{c}$ & $0,11 \pm 0,00 \mathrm{~b}$ & $5,35 \pm 0,02 \mathrm{a}$ \\
Whey tahu (J2) & $16,29 \pm 0,09 \mathrm{~b}$ & $3,37 \pm 0,002 \mathrm{~b}$ & $344,94 \pm 5,76 \mathrm{~b}$ & $0,13 \pm 0,00 \mathrm{~b}$ & $4,79 \pm 0,22 \mathrm{a}$ \\
Kulit nenas (J3 & $12,97 \pm 0,33 \mathrm{a}$ & $0,31 \pm 0,00 \mathrm{a}$ & $300,58 \pm 21,25 \mathrm{a}$ & $0,08 \pm 0,00 \mathrm{a}$ & $6,91 \pm 0,04 \mathrm{~b}$ \\
\hline$B N J_{0,05}$ & $\mathbf{2 , 0 8}$ & $\mathbf{0 , 1 1}$ & $\mathbf{1 2 5 , 5 4}$ & $\mathbf{0 , 0 2}$ & $\mathbf{0 , 7 6}$ \\
\hline
\end{tabular}

Catatan: Angka-angka pada kolom yang sama dan diikuti huruf yang sama menunjukkan tidak berbeda nyata

Tabel 3. Hasil Analisis Keragaman Taraf Nyata 5 Persen Sifat Mekanis, Rendemen dan Ketebalan Nata Kering dari Berbagai Bahan Baku Nata dan Metode Pemurnian dengan $\mathrm{NaOH}$

\begin{tabular}{llllll}
\hline Perlakuan & \multicolumn{5}{c}{ Parameter } \\
\cline { 2 - 6 } & $\begin{array}{l}\text { Kuat tarik } \\
\text { (Tensile } \\
\text { strength) }\end{array}$ & $\begin{array}{l}\text { Kemuluran } \\
\text { (Elongation) }\end{array}$ & $\begin{array}{l}\text { Modulus } \\
\text { Young }\end{array}$ & Ketebalan & Rendemen \\
\hline Jenis bahan nata $(\mathrm{J})$ & $\mathrm{S}$ & $\mathrm{S}$ & $\mathrm{S}$ & $\mathrm{S}$ & $\mathrm{S}$ \\
Metode pemurnian $(\mathrm{H})$ & $\mathrm{S}$ & $\mathrm{S}$ & $\mathrm{S}$ & $\mathrm{NS}$ & $\mathrm{NS}$ \\
Interaksi $(\mathrm{JxH})$ & $\mathrm{NS}$ & $\mathrm{NS}$ & $\mathrm{NS}$ & $\mathrm{NS}$ & $\mathrm{NS}$ \\
\hline
\end{tabular}

Catatan: $\mathrm{S}=$ berbeda nyata; $\mathrm{NS}$ = tidak berbeda nyata

Sifat mekanis lembaran selulosa bakteri (nata) kering yang diamati meliputi kuat tarik, kemuluran (elongasi) dan modulus Young. Sifat mekanis nata kering yang dibuat dari bahan baku air kelapa jauh lebih tinggi dibandingkan dengan yang terbuat dari bahan baku whey tahu dan kulit buah nenas dan dikeringkan dengan cara dijemur di bawah sinar matahari (Tabel 3). Sifat mekanis lembaran nata kering yang dimurnikan dengan cara hidrolisis mengunakan $\mathrm{NaOH} 0,1 \%$ bersuhu $100^{\circ} \mathrm{C}$ lebih tinggi daripada sifat mekanis lembaran nata yang menggunakan suhu $30^{\circ} \mathrm{C}$ seperti diperlihatkan pada Tabel 4.

Tabel 4. Pengaruh Metode Pemurnian Nata Terhadap Sifat Mekanis, Rendemen dan Ketebalan Lembaran Nata Kering

\begin{tabular}{lccccc}
\hline Metode & \multicolumn{5}{c}{ Parameter } \\
\cline { 2 - 6 } pemurnian & $\begin{array}{c}\text { Kuat tarik } \\
\text { (Tensile } \\
\text { strength) } \\
(\mathrm{MPa})\end{array}$ & $\begin{array}{c}\text { Kemuluran } \\
\text { (Elongation) } \\
(\%)\end{array}$ & $\begin{array}{c}\text { Modulus } \\
\text { Young }\end{array}$ & $\begin{array}{c}\text { Ketebalan } \\
(\mathrm{cm})\end{array}$ & $\begin{array}{c}\text { Rendemen } \\
(\%)\end{array}$ \\
\hline $\mathrm{H} 1$ & $30,95 \pm 0,19 \mathrm{~b}$ & $1,08 \pm 0,00 \mathrm{~b}$ & $1470,82 \pm 0,00 \mathrm{~b}$ & $0,10 \pm 0,00$ & $2,96 \pm 0,06$ \\
$\mathrm{H} 2$ & $15,12 \pm 0,05 \mathrm{a}$ & $0,78 \pm 0,002 \mathrm{a}$ & $714,68 \pm 29,17 \mathrm{a}$ & $0,11 \pm 0,00$ & $2,73 \pm 0,34$ \\
\hline$B N J_{0,05}$ & $\mathbf{0 , 6 9}$ & $\mathbf{0 , 0 6}$ & $\mathbf{7 6 , 2 8}$ & - & - \\
\hline
\end{tabular}

Catatan: Angka-angka pada kolom yang sama dan diikuti huruf yang sama menunjukkan berbeda tidak nyata; $\mathrm{H} 1=$ Pemurnian nata menggunakan $\mathrm{NaOH} 0,1 \%$ bertemperatur $100^{\circ} \mathrm{C}$ selama 30 menit; $\mathrm{H} 2=$ Pemurnian nata menggunakan $\mathrm{NaOH} 0,1 \%$ bersuhu $30^{\circ} \mathrm{C}$ selama 24 jam

\section{Sifat Fisik Nata Kering}

Warna

Pada akhir proses pengeringan, semua nata yang dihasilkan dari bahan baku berbeda menunjukkan warna kecoklatan terutama untuk bahan baku air kelapa dan kulit nenas. Proses pengeringan mengakibatkan terjadi reaksi pencoklatan (reaksi maillard) antara komponen bahan baku nata terutama antara komponen karbohidrat dan protein. Secara umum hasil penelitian ini tidak jauh berbeda dengan 
warna lembaran kering khitosan hasil penelitian Thakhiew, dkk., (2010).

Pemurnian nata dengan cara hidrolisis menggunakan $\mathrm{NaOH}$ bersuhu $100^{\circ} \mathrm{C}$ lebih efektif mengurangi komponen lemak dan protein nata sehingga warna nata setelah pengeringan lebih putih dan cerah dibandingkan dengan yang dihidrolisis menggunakan $\mathrm{NaOH}$ bertemperatur $30^{\circ} \mathrm{C}$. Hal ini diduga larutan $\mathrm{NaOH}$ yang bertemperatur lebih tinnggi mampu melonggarkan ikatan serabut halus selolosa yang mengikat dan menyelimuti seluruh permukaan bakteri dan pigmen yang terbentuk, sehingga bakteri dan pigmen yang terperangkap mudah tercuci. Hal ini didukung oleh pernyataan Zimmermann, dkk., (2010) dan Lin, dkk., (2013), serta Lavoine, dkk., (2012) yang menyebutkan bahwa serabut halus selulosa berbentuk pita, mengikat dan menyelimuti seluruh permukaan bakteri dalam bentuk jaringan tiga dimensi. Karena itu, pemurnian sangat membantu mendapatkan selulosa yang bebas dari bakteri dan pigmen yang ada dalam medium kultur. Ramidar, dkk., (2018) menyatakan bahwa ion $\mathrm{OH}^{-}$dari $\mathrm{NaOH}$ akan bereaksi menyabunkan lemak dan melarutkan protein. Perendaman dengan $\mathrm{NaOH}$ menyebabkan struktur selulosa akan membengkak dan memudahkan saat proses asetilasi.

\section{Bentuk Permukan dan Pengkerutan}

Bentuk permukaan lembaran nata kering berbahan air kelapa (J1) dan kulit nenas (J3) memiliki kenampakan permukaan yang lebih halus dan kerutan lebih sedikit, berbeda dengan bentuk permukaan nata kering yang dibuat dari bahan bakudari whey tahu. Lembaran nata kering yang terbentuk dari bahan baku air kelapa dan kulit nenas diduga memiliki benang-benang selulosa yang tipis dan halus menyelimuti pori-pori matriksnya. Struktur matriks selulosa bakteri seperti ini mempermudah keluarnya air selama pengeringan. Selain itu, tekanan udara panas selama pengeringan tidak merusak matrik selulosanya. Hal yang sama tampak pada permukaan nata yang dimurnikan dengan $\mathrm{NaOH}$ bersuhu $100^{\circ} \mathrm{C}$.

Permukaan sampel nata mengkerut setelah mengalami pengeringan. Tabel 1 menunjukkan bahwa lembaran nata berbahan baku whey tahu memiliki tingkat pengkerutan tertinggi yang ditandai dengan banyak guratan pada permukaan nata kering. Demikian juga dengan lembaran nata yang dihidrolisis menggunakan $\mathrm{NaOH}$ pada suhu $30^{\circ} \mathrm{C}$ mengalami pengkerutan lebih banyak daripada yang dihidrolisis $\mathrm{NaOH}$ bersuhu $100^{\circ} \mathrm{C}$. Ini mungkin disebabkan oleh panas diganti dengan udara yang bergerak selama pengeringan. Udara yang bergerak mendesak uap air dalam lembaran natakeluar ke permukaan untuk diuapkan, sementara itu, komponen lemak dan protein yang menyelimuti matrik selulosa bakteri masih cukup banyak. Komponen lemak dan protein yang masih cukup banyak tersisa akibat hidrolisis yang kurang sempurna menyebabkan penyerapan panas oleh komponen ini selama proses pengeringan menjadi lebih tinggi. Panas berlebihan ini merusak untaian matriks selulosa pada saat udara panas mendorong uap air dalam lembaran nata, keluar menembus permukaan.

\section{Ketebalan}

Tebal nata ketika dipanen sangat bervariasi diakibatkan aktivitas bakteri pembentuk nata yang tidak seragam. Karena itu ketebalan lembaran nata kering juga bervariasi tergantung pada jenis bahan baku dan metode pemurnian. Ketebalan nata kering berada pada kisaran $0,08-0,13 \mathrm{~cm}$. Ketebalan nata hasil penelitian ini jauh lebih tinggi dari hasil penelitian Purwiyandi dan Lidiasari (2009) yang membuat nata de coco dengan fermentasi selama 12 hari dan dikeringkan pada suhu $80^{\circ} \mathrm{C}$ selama 24 jam. Nata de coco kering yang dihasilkan memiliki ketebalan $0,05 \mathrm{~cm}$. Perbedaan komposisi media ini diduga berpengaruh terhadap kecepatan pertumbuhan Acetobacter xylinum sehingga ketebalan nata yang terbentuk dari ketiga jenis bahan limbah juga berbeda. Basrah, dkk., (2003) 
dalam Kumalaningsih (2014) menyatakan bahwa whey tahu mengandung glukosa sebanyak 92,0 $\mathrm{mg} / \mathrm{L}$. Kulit nenas mengandung karbohidrat sebesar 17,53\% dan gula reduksi 13,65\% (Wijana, dkk., 1991) dengan jenis gula berupa d-manosa, d-xilosa, 1-fruktosa dan d-glikosamin (Bries, 2008). Sementara itu, menurut Warisno dan Dahana (2009) kandungan karbohidrat air kelapa, whey tahu, dan kulit nenas berturut-turut adalah 3,71\%, 5,49\% dan 12,39\%. Menurut Raghunathan (2013) yang menyatakan bahwa sumber karbon berpengaruh terhadap hasil selulosa bakteri yang dihasilkan oleh Acetobacter xylinium. Gliserol sumber karbon yang paling banyak menghasilkan selulosa, disusul dengan glukosa, fruktosa, inositol dan sukrosa.

\section{Rendemen}

Rendemen lembaran kering selulosa bakteri yang dibuat dari air kelapa, whey tahu, dan kulit nenas berturut turut adalah $5,35 \%, 4,79 \%$ dan $6,91 \%$ atau setara dengan 0,53 g/L, 0,48 g/L dan 0,69 g/L (Tabel 3). Hasil penelitian ini lebih rendah dari rendemen nata kering yang terbuat dari air tebu yang sebesar 1,67 g/L (Ahmed, dkk., 2019). Iriyandi, dkk., (2014), melaporkan bahwa pengolahan nata dari limbah pengolahan tahu, menghasilkan rendemen nata segar berkisar 32,57\%-44,33\% pada inkubasi selama 12-16 hari. Pada media yang sesuai, maka semakin lama inkubasi bakteri $A$. xylinum akan memproduksi benang-benang selulosa, sehingga rendemen bioselulosa akan meningkat.

\section{Sifat Mekanik Nata Kering}

Kuat tarik (Tensile strength)

Kuat tarik merupakan salah satu sifat mekanis untuk mengukur kekuatan film. Kuat tarik adalah gaya tarik maksimum yang dapat ditahan oleh film selama pengukuran berlangsung sampai film terputus. Kuat tarik dari suatu film sangat berpengaruh terhadap kualitas dari film tersebut. Makin tinggi kekuatan tarik suatu film maka semakin bagus kualitas film tersebut (Iskandar, dkk., 2010). Kuat tarik lembaran nata kering hasil penelitian ini menunjukkan bahwa lembaran nata kering dari air kelapa mempunyai kuat tarik tertinggi, diikuti oleh lembaran nata yang dibuat dari whey tahu dan kulit nenas. Hasil penelitian Indrarti (2007) menunjukan bahwa nilai kuat tarik dari bioselulosa kering dari air kelapa adalah 83,74 MPa dan 2,62 MPa pada bioselulosa asetat (Radiman dan Yuliani, 2008). Menurut Krochta dan Johnston (1997), nilai kuat tarik bahan plastik yang mudah terurai yang memenuhi standar adalah berkisar antara 10-100 MPa. Sementara itu, nilai kuat tarik plastik polipropilen (PP) adalah 24,7 MPa. Karena itu, sifat mekanis nata yang dibuat dari ketiga jenis bahan limbah pertanian ini dari aspek kekuatan putusnya mendekati karakteristik plastik mudah terurai.

\section{Kemuluran (Elongation)}

Kemuluran (Elongasi) adalah perubahan pemanjangan maksimum dari film yang diukur dalam persen saat robek (Krochta, 1992). Oleh karena itu, persen elongasi dari film sangat mempengaruhi kualitas film tersebut. Jenis bahan baku dari air kelapa dan metode pemurnian dengan $\mathrm{NaOH}$ bertemperatur $100^{\circ} \mathrm{C}$ memberikan persen elongasi yang tertinggi. Air kelapa mengandung nutrisi yang tepat untuk pertumbuhan Acetobacter xylinum untuk menghasilkan bioselulosa secara maksimal. Bakteri ini tumbuh optimal pada medium air kelapa yang diindikasikan dari ketebalan nata yang terbentuk pada lama fermentasi yang sama. Semakin tebal nata berarti semakin banyak terbentuk sel ektraseluler yang mengandung selulosa.

Sementara itu, pemurnian bioselulosa dengan hidrolisis $\mathrm{NaOH}$ bersuhu $100^{\circ} \mathrm{C}$ lebih efektif meningkatkan kemurnian kandungan selulosa jika dibandingkan dengan hidrolisis dengan $\mathrm{NaOH}$ bersuhu $30^{\circ} \mathrm{C}$ dan persentase kemuluran (elongasi) menjadi lebih tinggi daripada jika dimurnikan dengan hidrolisis $\mathrm{NaOH}$ dingin. Menurut Dayanti (2006) dalam Iskandar, dkk., (2010), persen elongasi dipengaruhi juga oleh kandungan selulosa. Pada 
umumnya semakin sedikit rongga matriks tertutup lapisan benang halus pelikel nata, maka luas permukaan nata semakin besar. Semakin besar luas permukaan, maka kekuatan putusnya semakin kecil ( $\mathrm{P}=\mathrm{F} / \mathrm{A})$. Pemanjangan nata saat akan putus merupakan kebalikan dari kuat tarik dan modulus Young. Semakin besar elongasi, maka semakin kecil nilai kuat tarik dan modulus Young. Hasil penelitian ini menunjukan hasil berbeda, nilai elongasi sebanding dengan nilai kuat tarik dan modulus Young. Hasil penelitian ini sesuai dengan pendapat Iskandar, dkk., (2010) yang menyatakan bahwa persentase elongasi ini berbanding lurus dengan kuat tarik suatu film. Persentase elongasi ini juga dipengaruhi oleh kandungan selulosa. Persentase elongasi nata dari 3 jenis bahan baku limbah hasil pertanian ini berkisar antara 7,36\% - 0,31\%. Hasil penelitian Maryam (2017) menunjukkan bahwa nata de coco yang dibuat dengan fermentasi selama 2 minggu dan dimurnikan dengan $\mathrm{NaOH} 5 \mathrm{~N}$ memiliki persentase elongasi sebesar 11,3\%, sedangkan nata de coco kering hasil penelitian ini memiliki elongasi sebesar 7,36\%. Perbedaan konsentrasi $\mathrm{NaOH}$ yang digunakan untuk proses pemurnian dan lama fermentasi nata menyebabkan perbedaan nilai elongasi lembaran nata kering yang dihasilkan.

\section{Modulus Young}

Tingkat kekakuan selulosa bakteri dapat diketahui melalui penentuan modulusYoung. Jika nilai modulus Young semakin tinggi, maka selulosa bakteri tersebut akansemakin kaku (Rohaeti dan Rahayu, 2012). Modulus Young dapat ditentukan melalui perbandingan antara nilai kuat putus terhadap perpanjangan saat putus. Nilai modulus young nata kering dari air kelapa jauh lebih tinggi daripada nata dari bahan whey tahu dan kulit nenas. Hal ini dipengaruhi oleh pertumbuhan bakteri Acetobacter xylinum karena pada medium air kelapa, massa sel yang dihasilkan bertambah besar berbeda dengan medium whey tahu dan kulit nenas. Massa sel bakteri yang besar membentuk selulosa yang lebih banyak. Karena itu kandungan selulosa nata juga meningkat.

\section{KESIMPULAN DAN SARAN}

\section{Kesimpulan}

Interaksi antara jenis limbah hasil pertanian dan metode pemurnian tidak berpengaruh terhadap sifat fisik dan mekanis nata yang dikeringkan dengan cara penjemuran di bawah sinar matahari. Nata kering yang dibuat dari air kelapa limbah pembuatan kopra memiliki sifat fisik dan mekanis yang terbaik. Nata berwarna coklat krem, berpermukaan halus dan sedikit kerutan dengan ketebalan nata $0,11 \mathrm{~cm}$ dan rendemen kering sebesar 5,35\% $(0,54 \mathrm{~g} / \mathrm{L})$, serta kuat tarik, elongasi dan modulus young berturut-turut sebesar 74,40 $\mathrm{MPa}, 7,36 \%$ dan 2664,16 . Nata kering yang dihasilkan melalui pemurnian menggunakan $\mathrm{NaOH}$ $0,1 \%$ bertemperatur $100^{\circ} \mathrm{C}$ memiliki sifat fisik dan mekanis yang lebih baik dibandingkan dengan sifat fisik dan mekanis nata yang dimurnikan menggunakan $\mathrm{NaOH}$ $0,1 \%$ bertemperatur $30^{\circ} \mathrm{C}$. Warna nata lebih cerah, berpermukaan lebih halus dan lebih sedikit kerutan, namun ketebalan dan rendemen nata sama dengan kekuatan tarik, elongasi, dan modulus young berturut turut sebesar 30,95 MPa, 3,25\% dan 4412,25.

\section{Saran}

Pengeringan lembaran nata sebaiknya dilakukan di bawah naungan jika menggunakan metode penjemuran. Namun, jika pengeringan lembaran nata menggunakan alat pengering, sebaiknya dilakukan dengan cara menghembuskan udara panas bertemperatur kurang dari $40^{\circ} \mathrm{C}$ agar permukaan nata menjadi lebih halus dan tidak terbentuk kerutan.

Limbah cair tahu (whey) dapat menghasilkan lembaran nata dengan sifat seperti nata dari air kelapa, jika whey dibiarkan dahulu selama 24 jam sebelum diproses sebagai bahan baku nata.

Kulit buah nenas dapat menghasilkan nata dengan sifat fisik dan mekanis yang 
baik jika hasil perasan kulit buah (juice) dibersihkan dari kotoran fisik dengan cara pengendapan atau sentrifugasi dan pengaturan tingkat keasamaan $(\mathrm{pH})$ juice sebelum diinokulasikan strater Acetobacter xylinium.

\section{UCAPAN TERIMA KASIH}

Penelitian ini dilaksanakan dengan biaya bersumber dari dana DIPA BLU (PNBP) Universitas Mataram Tahun Anggaran 2019.

\section{DAFTAR REFERENSI}

Ahmed, S., Kanchi, S. \& Khumar, G. (2019). Handbook of Biopolymers: Advances and Multifaceted Application. Singapore: Pan Stanford Pte. Ltd.

Arrieta, M.P., Fortunati, E, Dominici F., Rayón, E., López, J., \&. Kenny, J.M. (2014). PLA-PHB/Cellulose Based Films: Mechanical, Barrier and Disintegration Properties. J. Polymer Degradation and Stability, 107, 139. 149.

Basak, A.K. (2013). Drying Characteristics of Bacterial Cellulose Produced FromFermentation of Black Tea by Symbiotic Colony of Yeast and Bacteria. IJSR, 4(6), 1144-1147.

Bielecki, S., Krystynowicz, A., Turkiewicz, M., Kalinowska, H. (2005). Bacterial Cellulose. In: Polysaccharides and Polyamides in the Food Industry, A. Steinbüchel, S.K. Rhee (Eds.), Wiley$\mathrm{VCH}$ Verlag, Weinheim, Germany, 31-85.

Bries, A.R. (2008). The Extraction of Bioethanol from Pineapple Peelings Through Simultaneous Saccharification and Fermentation using the Yeast Saccharomyces cerevisiae. Republic of the Philippines Cumhyriyet Filipinler.

Chawla, P.R., Bajaj, I.B., Survase, S.A. \& Singhal, R.S. (2009). Microbial cellulose: Fermentative production and applications. Food Technol. Biotechnol, 47(2), 107-124.

Gao, C., Yan, T., Du, J., He, F., Luo, H., \&Wan, Y. (2014). Introduction of Broad Spectrum Antibacterial Properties to Bacterial Cellulose Nanofibers via Immobilising EPolylysine Nanocoatings. Food Hydrocolloids, 36, 204-211.

Indrarti, L. (2007). Bioselulosa sebagai bahan edible film. Laporan Penelitian. Pusat Penelitian Fisika. LIPI.

Iryandi, A.F., Hendrawan, Y.\& Nur, K. (2014). Pengaruh penambahan air jeruk nipis (Citrus aurantifolia) dan lama fermentasi terhadap karakteristik nata de soya. Bioproses Komoditas Tropis, 1(10), 8-15.

Iskandar, Zaki, M., Mulyati, S., Fathanah, U., Sari, I., \& Juchairawati. (2010). Pembuatan film selulosa dari nata de pina. Rekayasa Kimia dan Lingkungan, 7(3), 105-111.

Krochta, J.M. (1992). Control of Mass Transfer in Food with Edible Coatings and Films. In: Singh, R.P. and M.A. Wirakartakusumah (eds). Advances in Food Engineering. CRP Press. Boca Raton, 519-538.

Krochta, J.M., \& Johnston, C.D.M. (1997). Edible and Biodegradable Polymer Film. Challenges and Opportunities. Food Tech, 51(2), 61-74.

Kumalaningsih, S. (2014). Pohon Industri Komoditi Hasil Pertanian Pada Sistem Agroindustri. Malang: UB Press. 
Lavoine, N., Desloges, I., Dufresne, A.\& Bras, J. (2012). Microfibrillated cellulose-Its barrier properties and applications in cellulosic materials: Areview. Carbohydrate polymers, 90(2), 735-764.

Lin, S.P., Calvar, I, Catchmark, J.M., Liu, J.R., Demirci, A. \&Cheng, K.C. (2013). Biosynthesis, production and applications of bacterial cellulose. Cellulose, 20(5), 2191-2219.dd.

Lin, W.C., Lien, C.C., Yeh, H.J., Yu, C.M., \& Hsu, S.H. (2013). Bacterial cellulose and bacterial cellulosechitosan membranes for wound dressing applications. Carbohydrate polymers, 94(1), 603-611.

Maryam, Dedy, R., \& Yunizurwan. (2017). Processing of micro-nano bacterial cellulose with hydrolysis method as a reinforcing bioplastic. J. Phys.: Conf. Ser., 795, 1-7.

Meftahia, A., Khajavib, R., Rashidia, A., Rahimic, M.K., \& Bahadord, A. (2015). Effect of Purification on Nano Microbial Cellulose Pellicle Properties. Procedia Materials Science, 11, 206-211.

Norhayati, P., Hamid, N.I.A., Khairudin N., \&Zahan, K.A. (2014). Effect of Different Drying Methods on the Morphology, Crystallinity, Swelling Ability and Tensile Properties of Nata De Coco. Sains Malaysiana, 43(5), 767-773.

Nguyen, V.T., Gidley, M.J., \& Dykes, G.A. (2008). Potential of a nisin-containing bacterial cellulose film to inhibit Listeria monocytogenes on processed meats. Food Microbiology, 25, 471478.

Pérez, C.D., De'Nobili, M.D., Rizzo, S.A., Gerschenson, L.N., Descalzo, A.M.,
\& Rojas, A.M. (2013). High Methoxyl Pectin-Methyl Cellulose Films with Antioxidant Activity at a Functional Food Interface. Journal of Food Engineering, 116, 162-169.

Pa'e, N., Hamid, N.I.A., Khaerudin, N., Zahan,K.A., Seng, K.F., Siddique, B.M., , \&, Muhammad, M.I. (2014). Effect of Different Drying Methods on the Morphology, Crystallinity, Swelling Ability Tensile Properties of Nata De Coco. Sains Malaysiana, 43(5), 767-773.

Purwiyanti \& Lidiasari, S. (2009). Bahan pengemas dan tepung selulosa yang dibuat dari nata de coco. AGRIA, 5(2), 24-28.

Radiman, C. \& Yuliani, G. (2008). Penggunaan nata de coco sebagai bahan membran selulosa asetat. Prosiding Simposium Nasional Polimer V-Bandung.

Rahmidar, L., Wahidiniati, S., \& Sudiarti, T. (2018). Pembuatan dan karakterisasi metil selulosa dari bonggol dan kulit nanas (Ananas comosus). Alotrop, 2(1), 88-96.

Raghunathan, D. (2013). Production of microbial cellulose from the new bacterial strain isolatedfrom temple wash waters. Int. J. Curr. Microbiol. App. Sci., 2(12), 275-290.

Reiniati, I., Hrymak, A. N., \& Margaritis, A. (2017). Recent developments in the production and applications of bacterial cellulose fibers and nanocrystals. Crit. Rev.Biotechnol., 37, 510-524.

Rohaeti, E, \& Rahayu, T. (2012). Sifatmekanik bacterial cellulose denganmedia air kelapa dan gliserol sebagaimaterial pemlastis. Prosiding Seminar Nasional Penelitian, 
Pendidikan dan Penerapan MIPA. FMIPA Universitas Negeri Yogyakarta.

Santos, S.M., Carbajo, J.M., Quintana, E., Ibarra, D., Gomez, N., Ladero, Eugenio, M.E.,\&Villar, J.C. (2014). Characterization of purified bacterial cellulose focused on its use onpaper restoration. Carbohydrate Polymers, 116, 173-181.

Snedecor, G. W., \& Cochran, W. G. (1994). Statistical methods (eighth edition). Calcutta, India: Oxford \& IBH Publishing Co.

Sonia, A., \& Dasan, K.P. (2013). Celluloses Microfibers (CMF)/Poly (EthyleneCo-Vinyl Acetate) (EVA) Composites for Food Packaging Applications: A Study Based on Barrier and Biodegradation Behavior. Journal of Food Engineering, 118(1), 78-89.

Suppakul, P., Jutakorn, K., \& Bangchokedee, Y. (2010). Efficacy of Cellulose-Based Coating on Enhancing The Shelf Life of Fresh Eggs. Journal of Food Engineering, 98, 207-213.

Tang, W., Jia, S., Jia, Y., \& Yang, H. (2010). The influence of fermentation conditions and posttreatment methods on porosity of bacterial cellulosemembrane. World Journal of Microbiology and Biotechnology, 26(1), 125-131.
Thakhiew, W., Devahastin, S. \& Soponronnarit, S. (2010). Effects of drying methods and plasticizer concentration on some physical and mechanical properties of edible chitosan films. Journal of Food Engineering, 99, 216-224.

Warisno \& Dahana, K. (2009). Inspirasi Usaha Membuat Nata. Jakarta: Agro Media Pustaka.

Wijana, S., Kumalaningsih, Setyowati, A., Efendi, U., \& Hidayat, N. (1991), Optimalisasi Penambahan Tepung Kulit Nanas dan Proses Fermentasi pada Pakan Ternak terhadap Peningkatan Kualitas Nutrisi. ARMP (Deptan). Universitas Brawijaya. Malang.

Zeng, M., Laromaine, A., \&Roig, A. (2014). Bacterial cellulose films: influence of bacterial strain and drying route on film properties. Cellulose, 21 , 4455-4469.

Zhu, H., Jia, S., Yang, H., Tang, W., Jia, Y., \&Tan, Z. (2010). Characterization of Bacteriostatic Sausage Casing: A Composite of Bacterial Cellulose Embedded with Polylysine. Food Science and Biotechnology, 19, 14791484.

Zimmermann, T., Bordeanu, N., \&Strub, E. (2010). Properties of nanofibrillated cellulose from different raw materials and its reinforcement potential. Carbohydrate Polymers, 79(4), 10861093. 